\title{
Variation in Sensitivity of Different Grapevine Genotypes to Erysiphe necator Growing under Unfavourable Climatic Conditions
}

\author{
S. Boso, P. Gago, J.L. Santiago, M.C. Martínez* \\ Misión Biológica de Galicia, Consejo Superior de Investigaciones Científicas (CSIC), Carballeira 8, 36143 Salcedo, Pontevedra, \\ Spain
}

Submitted for publication: August 2017

Accepted for publication: October 2017

Keywords: Clusters, leaves, Erysiphe necator, fungal diseases, incidence, Vitis vinifera, powdery mildew

\begin{abstract}
This paper reports the susceptibility to powdery mildew of 41 grapevine genotypes growing in the north and northwest of Spain over a three-year period. Although the humid climate of these vine-growing areas is not particularly favourable to the development of this disease, serious damages appears in some years when dry weather alternates with times of some rain. All the examined genotypes belonged to the collection of the Misión Biológica de Galicia (CSIC) (Pontevedra, Galicia, Spain). The incidence and severity of powdery mildew were determined on leaves three weeks after the onset of flowering and on clusters at harvest. The values for both variables were smaller than those recorded for other fungal diseases, although great differences in susceptibility between the different genotypes were observed. The most susceptible was Castañal (recently included in the Spanish Registry of Commercial Varieties), a genotype native to the $\mathbf{O}$ Rosal subzone of the Rias Baixas denomination of origin area. The present results could help viticulturalists grow different grapevine genotypes more successfully in regions with climatic conditions similar to those where the study was undertaken.
\end{abstract}

\section{INTRODUCTION}

Powdery mildew, a disease of vines caused by Erysiphe necator (Schw.) Burr., is very common in vineyards where, according to the classification of Koppen, the climate is of the Csa type (AEMET, 2010). In some years, however, it can also cause damage in areas with $\mathrm{Cfb}$ and Csb climates, such as in Galicia and Asturias (in the northwest and north of Spain respectively). E. necator survives the winter as a mycelium in the buds. In areas with a $\mathrm{Cfb}$ and $\mathrm{Csb}$ climate, the fungus extends in springtime via cleistothecia, which release ascospores that develop on leaves and other aerial organs (Pearson \& Gadoury, 1987; Jarvis et al., 2002). In Csa climate areas, however, the mycelia in the infected buds may simply grow into the leaves etc., without the production of such spores (Van der Spuy \& Mathee, 1977; Sall \& Wrysinski, 1982; Pearson \& Gartel, 1985). The disease appears as a whitish-grey powdery coating on the leaves and berries, i.e. the visible mycelium and conidia. Severe infections can debilitate vines, reduce net photosynthesis, delay ripening and reduce wine quality (Gadoury et al., 2001; Dry et al., 2010).

The initial symptoms on leaves are chlorotic spots on the upper surface that soon become whitish lesions. Late in the season, small, round black structures (cleistothecia) begin to appear within the white, powdery lesions (Gadoury et al.,
2012). It is on the clusters, however, where the infection causes the most commercial damage. Clusters appear to be most susceptible to attack between flower setting and véraison (Ypema \& Gubler, 2000; Gadoury et al., 2001); over this interval the berries can suffer considerable damage. The first cluster symptom is the appearance of a grey dust over the berries; those affected fail to develop properly and end up splitting, leaving the seeds exposed. This favours the entry of other pathogens such as Botrytis cinerea. If infection occurs after véraison, the berries may still grow, but the must quality can be seriously affected (Amati et al., 1996; Gadoury et al., 2001).

The environmental factors that limit the germination and growth of powdery mildew (temperature, rainfall and relative humidity) have been reported by several authors (Jarvis et al., 2002; Carroll \& Wilcox, 2003). The ideal conditions for the growth of powdery mildew include temperatures of 20 to $28^{\circ} \mathrm{C}$ (optimum range 24 to $27^{\circ} \mathrm{C}$ ), $80 \%$ to $90 \%$ relative humidity $(\mathrm{RH})$, and relatively low light levels (such as those found inside dense vine canopies or during overcast weather). Temperatures of over $35^{\circ} \mathrm{C}$ inhibit spore germination and slow the growth of the fungus, while temperatures of over $40^{\circ} \mathrm{C}$ kill the spores (Keller et al., 2003). Powdery mildew can tolerate low RH levels (e.g. of

*Corresponding author: E-mail address: carmenmartinez@mbg.csic.es [Tel.: +34 986854 800; Fax: +34 986841362$]$

Acknowledgements: We gratefully acknowledge the financial support of the Xunta de Galicia via research projects PGIDIT07PXIB403143PR, 07MRU024403PR, INCITE07PXI403090ES and INCITE08E1R403021ES, and the Ministerio de Ciencia y Tecnologia-INIA (Spain) via project RF 2008-00002-C02. The authors thank E. Zubiaurre, M.S. Taboada and I. González, for technical assistance, and Adrian Burton, for help with the English version of the manuscript 
around $40 \%$ ), but the production of conidia, and therefore the rate at which the disease spreads, appears greatest at over $80 \%$ RH. An RH of above $90 \%$ may not be as favourable given the formation of free water droplets; powdery mildew conidia burst or germinate abnormally in water.

Certain species of Vitis, such as $V$. riparia, $V$. rupestris, $V$. labrusca and $V$. rotundifolia, are resistant to powdery mildew (Mullins et al., 1992; Gadoury et al., 2012; Pap et al., 2016), but nearly all varieties of Vitis vinifera are susceptible, and some more so than others (Li, 1993; Staudt, 1997; Merdinoglu et al., 2014; Atak, 2017). Gaforio et al. (2011) compared the susceptibility of different $V$. vinifera genotypes in central Spain, where the climate is semi-arid (Csa, with hot, dry summers). The aim of the present work was to assess the susceptibility to powdery mildew of 41 genotypes of $V$. vinifera (some the same as in the latter study) growing in the north and northwest of the Iberian Peninsula (some for more than 400 years), where the fungus sometimes causes damage even though the summers are much cooler.

\section{MATERIALS AND METHODS \\ Plant material}

The vine material used in this work belonged to $41 \mathrm{~V}$. vinifera L. genotypes (19 white and 22 red, 10 plants per genotype, randomised block distribution), all part of the collection of the Misión Biológica de Galicia (CSIC). The plot where these genotypes are maintained lies $4 \mathrm{~km}$ from the town of Pontevedra, in Galicia (north-western Spain) $\left(42^{\circ} 25^{\prime} \mathrm{N}\right.$, $8^{\circ} 38^{\prime} \mathrm{W}$ ), at an altitude of $35 \mathrm{~m}$. The soil of this plot is a sandy loam ( $70.1 \%$ sand, $6.1 \%$ silt, $13.8 \%$ clay) with an organic matter content of $7.3 \%$. The plant rows are $2.5 \mathrm{~m}$ apart, with $2 \mathrm{~m}$ between plants, translating into a planting density of 2000 plants/ha. All plants are grown employing a trellis system, and are pruned using the Sylvoz method. During the study period, the plants were gown according to standard viticultural practices; no fungicides or pesticides were used in the experimental area.

Most of the studied genotypes were found in different places in the Iberian northwest, where they have existed for more than 400 years. However, some arrived in the area from different parts of Europe after the occurrence of phylloxera (e.g., Doña Blanca is from Castilla-León, Albarín blanco and Verdejo negro are from Asturias, Caíño blanco and Caíño tinto are from Galicia, Tempranillo is from La Rioja, Palomino is from Andalusia, Cabernet Sauvignon, Chenin blanc and Sauvignon blanc are from France, and Chasselas Dorée is from France or Switzerland, etc.).

The mean annual temperature for the last 50 years at the plot site is $14.11^{\circ} \mathrm{C}$; the mean annual rainfall for the same period is $1686.68 \mathrm{~mm}$ (data recorded by a weather station on the plot). Over the study period (2009 to 2011), temperature, rainfall and relative humidity data were recorded at the same weather station (Fig. 1).

\section{Evaluation of disease symptoms}

In the experimental plot, primary infection is caused by ascospores released in spring via cleistothecia. The vines were monitored weekly for spores from spring onwards by collecting 10 to 15 basal leaves from approximately 50 plants at random and examining the underside of the leaves. Once the presence of spores was confirmed, leaf disease incidence and severity were recorded in 10 vines per genotype at about three weeks after the onset of flowering. The same variables were determined in clusters at harvest in 2009, 2010 and 2011. Disease incidence was determined as number of leaves or clusters with symptoms/total number of leaves or clusters) $\times 100$, and disease severity as (area of the leaves or cluster affected/leaves or clusters surface area $) \times 100$. The resistance level of each genotype to powdery mildew was rated based on its severity index (SI) (Wang et al., 1995).

For the sake of comparison with the results of other authors (Gubler et al., 1999, Péros et al., 2006; Gaforio et al., 2011), the 'degree of susceptibility' shown by the different genotypes was also measured using the method of the Organisation of Vine and Wine (code 455 and 456) (OIV, 2009). This involves a scale from 1 to 9: a score of 1 to 3 reflects very low to low resistance (high susceptibility), 5 represents medium resistance (medium susceptibility), and a score of 7 to 9 indicates high to very strong resistance (low susceptibility).

\section{Statistical analysis}

The results were subjected to ANOVA. Means were compared using the least mean squares procedure. All calculations were performed using SAS System v. 8.1 software (SAS, 2000).

\section{RESULTS}

Springtime (May) temperatures over the study period were low (mean temperature $<15^{\circ} \mathrm{C}$ in all years of the study). This prevented strong powdery mildew attacks during this period; infections did occur, but the spread of disease was slow. Conditions were most favourable for the fungus between flowering (June) and véraison (August). Over this period the mean temperature was $>17^{\circ} \mathrm{C}$ and the maximum temperatures were $<33^{\circ} \mathrm{C}$ in all years of the study. Over most of the study period the relative humidity was between $69 \%$ and $80 \%$ (Fig. 1).

No powdery mildew symptoms were observed on the leaves at flowering for nearly all genotypes and over all three years of the study. Only the genotypes Castañal, Mouratón and Torrontés (disease incidence 25\%, 15\% and $18 \%$ respectively) showed higher susceptibility to this disease at this moment during the growth cycle in 2011.

For the clusters, however, significant differences were seen between genotypes in terms of disease incidence and severity over the three years of the study. The interaction genotype x year had a significant influence on these variables; the results were therefore analysed for each separate year. Incidence and severity were worse in 2011 than in the other years. The genotype Castañal showed the highest disease incidence (46\% in $2009,76 \%$ in 2010 and $98 \%$ in 2011) and severity (75\% in 2009 and 2010 and $85 \%$ in 2011) in every year of the study; indeed, the values recorded were significantly higher than for all other genotypes.

Among the remaining genotypes, the most susceptible, i.e. showing significantly greater disease incidence and severity than the others (Table 1), was Blanca Desconocida 1 in 2009 (incidence 24\%, severity 25\%), Caíño Bravo in 2010 (14\% and 28\%), and Mouratón (48\% and 45\%) and Verdello 


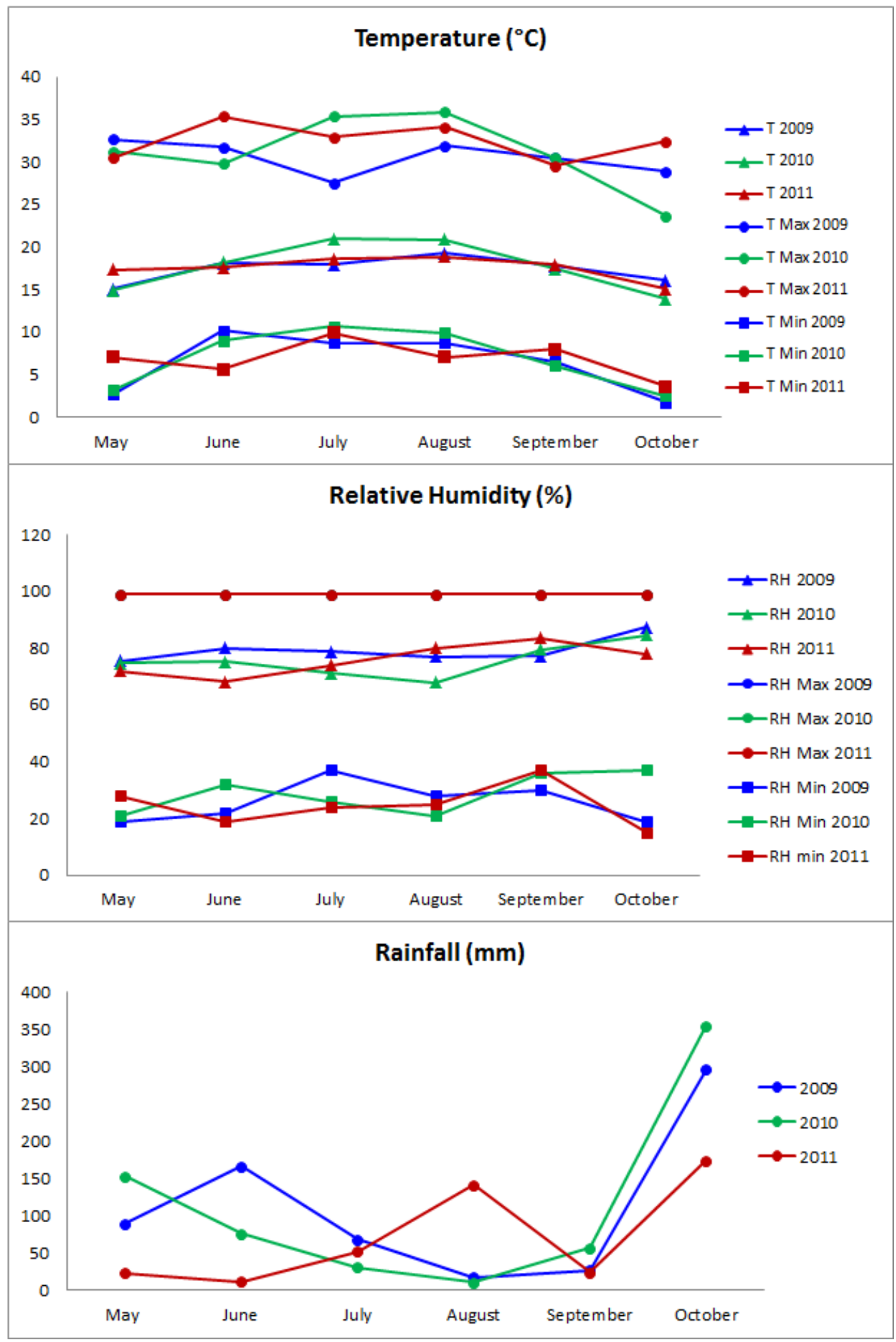

FIGURE 1

Weather data for the study period (2009 to 2011).

tinto (34\% and 38\%) in 2011. Many genotypes (Blanca Cabanelas, Godello, Chasselas Doré, Albarín blanco, Petit Bouschet, Albarín Francés and Silveiriña) never showed any symptoms of disease (i.e. zero disease incidence and severity) in any year. The genotypes Torrontés, Couxo, Caíño tinto, Caíño Longo, Alicante Henri Bouschet, Verdejo negro, Chenin blanc, Tempranillo, Albariño, Prieto Picudo, Pedral, Verdello tinto, Carrasco and Cabernet Sauvignon also showed very low susceptibility (incidence $<10 \%$ in all years, severity $0 \%$ to $25 \%$ depending on the year). According to the criteria of the OIV (OIV, 2009), nearly all the genotypes showed high resistance $(\mathrm{H})$ to powdery mildew. Castañal, however, showed low (L) leaf resistance (code 455) in all study years and medium (M) cluster resistance (code 456) in 2009. Mouratón also showed medium cluster resistance (code 456) in 2011. 
TABLE 1

Disease incidence (\%) and severity (\%) in the different genotypes.

\begin{tabular}{|c|c|c|c|c|c|c|}
\hline \multirow{2}{*}{ Genotype } & \multicolumn{2}{|c|}{2009} & \multicolumn{2}{|c|}{2010} & \multicolumn{2}{|c|}{2011} \\
\hline & Incidence & Severity & Incidence & Severity & Incidence & Severity \\
\hline Castañal (R) & $46.30 \mathrm{a}^{*}$ & $75 \mathrm{a}$ & $76.4 \mathrm{a}$ & $75 \mathrm{a}$ & $97.53 \mathrm{a}$ & $85 a$ \\
\hline Blanca Desconocida $1(\mathrm{~W})$ & $23.55 b$ & $25 \mathrm{c}$ & $0 \mathrm{c}$ & $0 \mathrm{c}$ & $1.07 \mathrm{f}$ & $1.2 \mathrm{~g}$ \\
\hline Torrontés (W) & $9.51 \mathrm{c}$ & $25 \mathrm{c}$ & $0.96 \mathrm{c}$ & $0 \mathrm{c}$ & $27.73 \mathrm{~cd}$ & $15.5 \mathrm{cde}$ \\
\hline Caíño tinto (R) & $5.59 \mathrm{c}$ & $5 \mathrm{~d}$ & $0 \mathrm{c}$ & $0 \mathrm{c}$ & $3.40 \mathrm{f}$ & $2.5 \mathrm{fg}$ \\
\hline Caíño Longo (R) & $5.00 \mathrm{c}$ & $50 \mathrm{~b}$ & $0 \mathrm{c}$ & $0 \mathrm{c}$ & 19.36de & $23 \mathrm{c}$ \\
\hline Mouratón (R) & $3.85 \mathrm{c}$ & $5 \mathrm{~d}$ & $2.17 \mathrm{c}$ & $2 \mathrm{c}$ & $48.39 \mathrm{~b}$ & $45 \mathrm{~b}$ \\
\hline Alicante Henri Bouschet (R) & $2.96 \mathrm{c}$ & $5 d$ & $0 \mathrm{c}$ & $0 \mathrm{c}$ & $6.32 \mathrm{f}$ & $6 \mathrm{efg}$ \\
\hline Treixadura (W) & $2.60 \mathrm{c}$ & $5 d$ & $0 \mathrm{c}$ & $0 \mathrm{c}$ & of & $0 \mathrm{~g}$ \\
\hline Verdejo negro (R) & $2.01 \mathrm{c}$ & $5 d$ & $0 \mathrm{c}$ & $0 \mathrm{c}$ & $1.26 \mathrm{f}$ & $1.2 \mathrm{~g}$ \\
\hline Chenin blanc (W) & $1.60 \mathrm{c}$ & $5 d$ & $0 \mathrm{c}$ & $0 \mathrm{c}$ & $0.43 \mathrm{f}$ & $0.06 \mathrm{~g}$ \\
\hline Tempranillo (R) & $1.27 \mathrm{c}$ & $5 \mathrm{~d}$ & $0 \mathrm{c}$ & $0 \mathrm{c}$ & $19.24 \mathrm{de}$ & $6 \mathrm{efg}$ \\
\hline Albariño (W) & $1.10 \mathrm{c}$ & $5 \mathrm{~d}$ & $0 \mathrm{c}$ & $0 \mathrm{c}$ & $1.92 \mathrm{f}$ & $1.6 \mathrm{fg}$ \\
\hline Sauvignon blanc (W) & $1.02 \mathrm{c}$ & $0 \mathrm{~d}$ & $0 \mathrm{c}$ & $0 \mathrm{c}$ & of & $0 \mathrm{~g}$ \\
\hline Albarín negro (R) & $0.71 \mathrm{c}$ & $5 \mathrm{~d}$ & $0 \mathrm{c}$ & $0 \mathrm{c}$ & of & $0 \mathrm{~g}$ \\
\hline Prieto Picudo (R) & $0.68 \mathrm{c}$ & $5 d$ & $0 \mathrm{c}$ & $0 \mathrm{c}$ & $10.87 \mathrm{ef}$ & $12 \mathrm{def}$ \\
\hline Pedral (R) & $0.54 \mathrm{c}$ & $5 \mathrm{~d}$ & $0 \mathrm{c}$ & $0 \mathrm{c}$ & $4.58 \mathrm{f}$ & $2.2 \mathrm{fg}$ \\
\hline Palomino (W) & $0.46 \mathrm{c}$ & $0 \mathrm{~d}$ & $0 \mathrm{c}$ & $0 \mathrm{c}$ & $0 \mathrm{f}$ & $0 \mathrm{~g}$ \\
\hline Couxo (R) & $0.43 \mathrm{c}$ & $5 \mathrm{~d}$ & $0.64 \mathrm{c}$ & $0.07 \mathrm{c}$ & $1.69 \mathrm{f}$ & $1.6 \mathrm{fg}$ \\
\hline Caíño blanco (W) & $0.20 \mathrm{c}$ & $5 d$ & $0 \mathrm{c}$ & $0 \mathrm{c}$ & Of & $0 \mathrm{~g}$ \\
\hline Blanca Cabanelas (W) & $0 \mathrm{c}$ & $0 \mathrm{~d}$ & $0 \mathrm{c}$ & $0 \mathrm{c}$ & of & $0 \mathrm{~g}$ \\
\hline Monstruosa (W) & $0 \mathrm{c}$ & $0 \mathrm{~d}$ & $0 \mathrm{c}$ & $0 \mathrm{c}$ & of & $0 \mathrm{~g}$ \\
\hline Verdello tinto (R) & $0 \mathrm{c}$ & $0 \mathrm{~d}$ & $1 \mathrm{c}$ & $20 \mathrm{~b}$ & $33.38 \mathrm{c}$ & $38 b$ \\
\hline Loureiro blanco (W) & $0 \mathrm{c}$ & $0 \mathrm{~d}$ & $0 \mathrm{c}$ & $0 \mathrm{c}$ & of & $0 \mathrm{~g}$ \\
\hline Brancellao blanco (W) & $0 \mathrm{c}$ & $0 \mathrm{~d}$ & $0 \mathrm{c}$ & $0 \mathrm{c}$ & of & $0 \mathrm{~g}$ \\
\hline Godello (W) & $0 \mathrm{c}$ & $0 \mathrm{~d}$ & $0 \mathrm{c}$ & $0 \mathrm{c}$ & of & $0 \mathrm{~g}$ \\
\hline Moscatel Grano Menudo Blanco (W) & $0 \mathrm{c}$ & $0 \mathrm{~d}$ & $0 \mathrm{c}$ & $0 \mathrm{c}$ & of & $0 \mathrm{~g}$ \\
\hline Doña Blanca (W) & $0 \mathrm{c}$ & $0 \mathrm{~d}$ & $0 \mathrm{c}$ & $0 \mathrm{c}$ & of & $0 \mathrm{~g}$ \\
\hline Silveiriña (W) & $0 \mathrm{c}$ & $0 \mathrm{~d}$ & $0 \mathrm{c}$ & $0 \mathrm{c}$ & $0 \mathrm{f}$ & $0 \mathrm{~g}$ \\
\hline Chasselas Doré (W) & $0 \mathrm{c}$ & $0 \mathrm{~d}$ & $0 \mathrm{c}$ & $0 \mathrm{c}$ & of & $0 \mathrm{~g}$ \\
\hline Albarín blanco (W) & $0 \mathrm{c}$ & $0 \mathrm{~d}$ & $0 \mathrm{c}$ & $0 \mathrm{c}$ & of & $0 \mathrm{~g}$ \\
\hline Morrastrel Bouschet (R) & $0 \mathrm{c}$ & $0 \mathrm{~d}$ & $0 \mathrm{c}$ & $0 \mathrm{c}$ & of & $0 \mathrm{~g}$ \\
\hline Ferrol (R) & $0 \mathrm{c}$ & $0 \mathrm{~d}$ & $0 \mathrm{c}$ & $0 \mathrm{c}$ & of & $18 \mathrm{~cd}$ \\
\hline Caíño Bravo (R) & $0 \mathrm{c}$ & $0 \mathrm{~d}$ & $14.31 \mathrm{~b}$ & $28 b$ & of & $0 \mathrm{~g}$ \\
\hline Follajeiro (R) & $0 \mathrm{c}$ & $0 \mathrm{~d}$ & $0 \mathrm{c}$ & $0 \mathrm{c}$ & of & $0 \mathrm{~g}$ \\
\hline Petit Bouschet (R) & $0 \mathrm{c}$ & $0 \mathrm{~d}$ & $0 \mathrm{c}$ & $0 \mathrm{c}$ & $0 \mathrm{f}$ & $0 \mathrm{~g}$ \\
\hline Moscatel Grano Menudo Rojo (R) & $0 \mathrm{c}$ & $0 \mathrm{~d}$ & $0 \mathrm{c}$ & $0 \mathrm{c}$ & $0 \mathrm{f}$ & $0 \mathrm{~g}$ \\
\hline Albarín Francés (R) & $0 \mathrm{c}$ & $0 \mathrm{~d}$ & $0 \mathrm{c}$ & $0 \mathrm{c}$ & of & $0 \mathrm{~g}$ \\
\hline Carrasco (R) & $0 \mathrm{c}$ & $0 \mathrm{~d}$ & $1.19 \mathrm{c}$ & $0.08 \mathrm{c}$ & $3.72 \mathrm{f}$ & $2.5 f g$ \\
\hline Cabernet Sauvignon (R) & $0 \mathrm{c}$ & $0 \mathrm{~d}$ & $2.5 \mathrm{c}$ & $1 \mathrm{c}$ & $0.42 \mathrm{f}$ & $1 \mathrm{~g}$ \\
\hline Mencia (R) & $0 \mathrm{c}$ & $0 \mathrm{~d}$ & $0 \mathrm{c}$ & $0 \mathrm{c}$ & of & $0 \mathrm{~g}$ \\
\hline Blanca Desconocida $2(\mathrm{~W})$ & $0 \mathrm{c}$ & $0 \mathrm{~d}$ & $0 \mathrm{c}$ & $0 \mathrm{c}$ & of & $0 \mathrm{~g}$ \\
\hline L.S.D. $(0.05)$ & 10.20 & 7 & 5.58 & 8 & 12.22 & 10 \\
\hline
\end{tabular}

Values in the same column followed by the same letter are not significantly different (i.e. P $>0.05$ ). W (white), R (red). 


\section{DISCUSSION}

As expected, the climatic conditions greatly influenced disease incidence and severity. Until May, the minimum temperature recorded was always $<15^{\circ} \mathrm{C}$ in all years of the study. This led to disease symptoms being absent. In all three years, the mean temperature from June to October was $>15^{\circ} \mathrm{C}$, which favoured fungal growth and the appearance of symptoms to a greater extent.

Several authors (Pearson \& Gadoury, 1987; Jarvis et al., 2002) report that, while some moisture is needed for symptoms to appear, excessive rainfall slows the growth and spread of the fungus. In 2009 and 2010, the high rainfall in May and June (75 to $165 \mathrm{~mm}$ ) slowed the spread of the disease, while in 2011 disease incidence and severity were high due to the lack of rainfall. From the end of July in 2009 and 2011, intermittent rainfall again prevented strong disease development. In 2010, the lack of rain and maximum temperatures of $>35^{\circ} \mathrm{C}$ for one week at the end of July reduced both the incidence and severity of disease.

In central Spain (Alcalá de Henares), which has a drier climate with hotter summers and colder winters, Gaforio et al. (2011) reported the genotype Torrontés to show low resistance to powdery mildew, while in the present work this genotype was associated with a mean incidence of $13 \%$ and a mean severity of $13.5 \%$ (low susceptibility according to the OIV scale). In contrast, while Gaforio et al. (2011) described the genotypes Chasselas Doré and Doña blanca to be of medium resistance (according to the OIV scale), and Mencía and Godello to show low resistance, in the present work these genotypes showed no symptoms at all in any year. The genotypes Caíño tinto, Prieto Picudo, Loureiro blanco and Petit Bouschet showed high resistance in both central and north-western Spain, despite the differences in climate.

In the present work, the genotypes Cabernet Sauvignon, Chenin blanc and Moscatel de Grano Menudo Blanco showed low susceptibility ("H" according to the OIV scale), but have been classed as very susceptible by other authors working in different countries with different climates (Li, 1993, Gubler et al., 1999, Péros et al., 2006). Atak (2017), who compared $V$. labrusca genotypes and interspecific cultivars grown in humid and dry regions, reported them to be resistant independent of the climate. Other authors indicate that, in several genotypes, resistance or susceptibility may differ between isolates (Montarry et al., 2008, 2009; Frenkel et al., 2012). Samples of the pathogen from areas of different climates are currently being characterised at our facility, and plants are being artificially inoculated to determine the effects $E$. necator races may have.

\section{CONCLUSIONS}

In conclusion, of the 41 genotypes studied, Castañal showed the greatest susceptibility to powdery mildew. This red grape genotype, a native of the O Rosal subzone of the Rías Baixas Denomination of Origin area (Northwest of Spain), was only recently included in the Spanish Registry of Commercial Varieties (Santiago et al., 2008). Huetz de Lemps (1967) describes it as highly susceptible to powdery mildew. The remaining genotypes showed low or no susceptibility. Comparison of the present results with those for some of the same genotypes grown in central Spain by other authors suggest that these genotypes are less susceptible to powdery mildew in humid regions, probably as a consequence of climate. The present results may help viticulturalists grow some genotypes more successfully in regions with climatic conditions similar to those of the study region.

\section{LITERATURE CITED}

AEMET (Agencia Estatal de Meteorología) (ed.), 2010. Visor del Atlas climático de la Península y Baleares (periodo de referencia: 1971-2010). Available at: www.aemet.es

Amati, A., Piva, A., Castellari, M. \& Arfelli, G., 1996. Preliminary studies on the effect of Oidium tuckeri on the phenolic composition of grapes and wines. Vitis 35, 149-150.

Atak, A., 2017. Determination of downy mildew and powdery mildew resistance of some grape cultivars. S. Afr. J. Enol. Vitic. 38, 11-17.

Carroll, J.E. \& Wilcox, W.F., 2003. Effect of humidity on the development of grapevine powdery mildew. Phytopathology 93, 1137-1144.

Dry, I.B., Feechan, A., Anderson, C., Jermakow, A.M., Bouquet, A., AdamBlondon A.F. \& Thomas, M.R., 2010. Molecular strategies to enhance the genetic resistance of grapevines to powdery mildew. Aust. J. Grape Wine Res. 16, 94-105.

Frenkel, O., Portillo, I., Brewer, M.T., Péros, J.P., Cadle-Davidson, L. \& Milgroom, M.G., 2012. Development of microsatellite markers from the transcriptome of Erysiphe necator for analysing population structure in North America and Europe. Plant Pathol. 61, 106-119.

Gadoury, D.M., Cadle-Davidson, L., Wilcox, W.F., Dry, I.B., Seem, R.C. \& Milgroom, M.G., 2012. Grapevine powdery mildew (Erysiphe necator): A fascinating system for the study of the biology, ecology and epidemiology of an obligate biotroph. Mol. Plant Pathol. 13, 1-16.

Gadoury, D.M., Seem, R.C., Pearson, R.C., Wilcox, W.F. \& Dunst, R.M., 2001. Effects of powdery mildew on vine growth, yield and quality of Concord grapes. Plant Dis. 85, 137-140.

Gaforio, L., García-Muñoz, S., Cabello, F. \& Muñoz-Organero, G., 2011. Evaluation of susceptibility to powdery mildew (Erysiphe necator) in Vitis vinifera varieties. Vitis 50(3), 123-126.

Gubler, W.D., Rademacher, M.R. \& Vasquez, S.J., 1999. Control of powdery mildew using the UC Davis Powdery Mildew Risk Index. APSnet Features. doi:10.1094/APSnetFeature-1999-0199.

Huetz de Lemps, A., 1967. Vineyards and wines in Northwest of Spain. Volumes I-II. Institute of Geography. Faculty of Arts. [Vignobles et vins du Nord-Ouest de 1'Espagne. Tomos I-II. Institut de Géographie. Faculté des Lettres, Bordeaux (in French)].

Jarvis, W.R., Gubler, W.D. \& Grove, G.G., 2002. Epidemiology of powdery mildews in agricultural pathosystems. In: Bélanger R.R., Bushnell, W.R., Dikana, A.J. \& Timothy, L.W. (eds). The powdery mildews: A comprehensive treatise. St. Paul, Minnesota, USA. pp. 169 - 199.

Keller, M., Rogiers, S.Y. \& Schultz, H.R., 2003. Nitrogen and ultraviolet radiation modify grapevines' susceptibility to powdery mildew. Vitis 42 , 87-94.

Li, H., 1993. Studies on the resistance of grapevine to powdery mildew. Plant Pathol. 42, 792-796.

Merdinoglu, D., Blasi, P., Wiedemann-Merdinoglu, S., Mestre, P., Peressotti, E., Poutaraud, A., Prado, E. \& Schneider, C., 2014. Breeding for durable resistance to downy and powdery mildew in grapevine. Acta Hortic. 1046, $65-72$. 
Montarry, J., Cartolaro, P., Delmotte, F., Jolivet, J. \& Willocquet, L., 2008 Genetic structure and aggressiveness of Erysiphe necator populations during grapevine powdery mildew epidemics. Appl. Environ. Microbiol. $74,6327-6332$

Montarry, J., Cartolaro, P., Richard-Cervera, S. \& Delmotte, F., 2009. Spatio-temporal distribution of Erysiphe necator genetic groups and their relationship with disease levels in vineyards. Eur. J. Plant Pathol. 123, 6170

Mullins, M.G., Bouquet, A. \& Williams, L.E., 1992. Biology of the grapevine. Cambridge University Press, New York.

OIV, 2009. The OIV descriptor list for grape varieties and Vitis species. Ed Dedon, Paris

Pap, D., Riaz, S., Dry, I.B., Jermakow, A., Tenscher, A.C., Cantu, D., Oláh, R. \& Walker, M.A., 2016. Identification of two novel powdery mildew resistance loci, Ren6 and Ren7, from the wild Chinese grape species Vitis piasezkii. BMC Plant Biol. 16(1), 170.

Pearson, R.C. \& Gadoury, D.M., 1987. Cleistothecia, the source of primary inoculum for grape powdery mildew in New York. Phytopathology 77, 1509-1514.

Pearson, R.C. \& Gartel, W., 1985. Occurrence of hyphae of Uncinula necator in buds of grapevine. Plant Dis. 69, 149-151.
Péros, J.P., Nguyen, T.H., Troulet, C., Michel-Romiti, C. \& Notteghem, J.L., 2006. Assessment of powdery mildew resistance of grape and Erysiphe necator pathogenicity using a laboratory assay. Vitis 45(1), 29-36.

Sall, M.A. \& Wrysinski., J., 1982. Perennation of powdery mildew in buds of grapevine. Plant Dis. 66, 678-679.

SAS Institute Inc., 2000. SAS OnlineDoc, version 8. SAS institute, Inc., Cary, North Carolina, U.S.A.

Santiago, J.L., Boso, S., Gago, P., Alonso-Villaverde, V. \& Martínez, M.C., 2008. A contribution to the maintenance of grapevine diversity: The rescue of Tinta Castañal (Vitis vinifera L.), a variety on the edge of extinction. Scientia Hortic. 116(2), 199-204.

Staudt, G., 1997. Evaluation of resistance to grapevine powdery mildew (Uncinula necator [Schw.] Burr., anamorph Oidium tuckeri Berk.) in accessions of Vitis species. Vitis 36, 151-154.

Van der Spuy, J.E. \& Mathee, F.N., 1977. Overwintering of the Oidium stage of Uncinula necator in the buds of the grapevine. Plant Dis. 61, 612615 .

Wang, Y., Li, Y., He, P., Chen, J., Lamikanra, O. \& Lu, J., 1995. Evaluation of foliar resistance to Uncinula necator in Chinese wild Vitis species. Vitis $34,159-164$.

Ypema, H.L. \& Gubler, W.D., 2000. The distribution of early season grapevine shoots infected by Uncinula necator from year to year: A case study in two California vineyards. Am. J. Enol. Vitic. 51, 1-6. 